\title{
Public Attitudes Toward Chairside Screening for Medical Conditions in Dental Settings
}

This article was published in the following Dove Press journal:

Patient Preference and Adherence

\author{
Azizah Bin Mubayrik (D) \\ Sara Al Dosary $\mathbb{D}^{\prime}$ \\ Reema Alshawaf ${ }^{\prime}$ \\ Reem Alduweesh ${ }^{2}$ \\ Shada Alfurayh ${ }^{2}$ \\ Tagreed Alojaymi ${ }^{2}$ \\ Malath Tuwaym ${ }^{2}$ \\ Daniyah Alsuhaibani ${ }^{2}$ \\ Ebtihal Aldaghri \\ 'Oral Medicine and Diagnostic Science \\ Department, King Saud University, \\ Riyadh, Saudi Arabia; ${ }^{2}$ College of \\ Dentistry, King Saud University, Riyadh, \\ Saudi Arabia
}

Objective: The aim of this study is to investigate the public's attitudes and knowledge toward chairside dental screening and laboratory investigations based on demographic data. Methods: A self-administered structured questionnaire regarding chairside screening was designed employing a 5-point Likert-type scale. The questionnaire was distributed to among sample of adults. Data were collected and statistically analyzed using descriptive statistics, $t$-tests, ANOVA, and $P$ values.

Results: A total of 573 questionnaires were completed. Most respondents were willing to have a dentist conduct screening for diseases, in particular blood measurement $(89 \%)$, hypertension (85.7\%) and lab result discussion (83.1\%), having medical condition did not affect the willingness. The lowest reported willingness was to undergo biopsy (54\%) and hepatitis screening (67.6\%) Age, education, hospital, and prior chairside screening were found to be significant factors for willingness.

Conclusion: The population's willingness to undergo chairside medical screenings in the dental office is crucial for the implementation of this strategy and to deliver a holistic approach to treating patients' medical conditions.

Keywords: chairside screening, dental, medical conditions, public

\section{Introduction}

Monitoring patients closely while in the dental chair is an essential task for the identification of both oral and general risks as well as for the early detection of systemic diseases. It also assists in identifying individuals with an increased risk for a disease or complication, early detection, and prompt intervention. ${ }^{1-6}$ A considerable proportion of the population has reported visiting the dentist but not seeing their physicians. ${ }^{7,8}$ Improved patient health is associated with dental involvement, including improved quality of life. ${ }^{9}$ In addition, a holistic patient approach is recommended for optimal health. ${ }^{10}$ Several studies have investigated the benefits of medical screening at the dental chairside as well as the beliefs and attitudes among dentists, authorities, and patients on this topic, with a favorable response reported. ${ }^{11-17}$ Most of the emphasis in the literature on chronic noncommunicable diseases has focused on efforts to decrease the morbidity and mortality of those diseases. For example, heart diseases are considered to be one of the leading causes of death. ${ }^{18}$ Studies have demonstrated that dental screening identified the risk of developing cardiac diseases and serious complications and that they played a role in instituting early intervention. $^{5,19}$ Similarly, reports on diabetes mellitus, a common disease with a considerable associated morbidity, complications, and mortality have revealed promising results. Indeed, research has indicated that screening within dental clinics is an
Correspondence: Azizah Bin Mubayrik Oral Medicine and Diagnostic Science, Department, College of Dentistry, King Saud University, 3680 King Saud

University Unit No. 3ar, Riyadh 12372

-7453, Kingdom of Saudi Arabia

Email aalmobeirik@ksu.edu.sa
Patient Preference and Adherence 2021:15 187-195 in $\square$ 
effective means of early detection of prediabetes and diabetes. ${ }^{20}$ Researchers have found positive patient attitudes and willingness toward chairside dental screening. ${ }^{13,15,21-23}$ In a qualitative study, patients who underwent chairside screening requested regular screening in the dental clinic. ${ }^{23}$ However, most of these studies investigated chronic diseases such as diabetes and cardiovascular disease. There have been few studies in the reviewed English literature that has examined attitudes toward screening for other common diseases, and none were conducted in Saudi, this is the first such study in Saudi Arabia assessing public attitudes. The aim of this study is to explore the public's attitudes and knowledge toward chairside dental screening and laboratory investigations against demographic data.

\section{Materials and Methods}

A cross-sectional survey was designed and conducted to explore the public's attitudes and knowledge toward chairside dental screening and laboratory investigations. After we reviewed the current literature on this topic, we designed and constructed a structured self-administered questionnaire to fulfill the study objectives. The questionnaire was developed in Arabic in different questioning types. The questionnaire was divided into the following three parts. Part 1 contained questions about demographic data, namely, age, sex, education level, occupation, marital status, medical conditions, last visit, and whether medical consultation by the dentist was received. Part 2 included questions related to the willingness to undergo screening. This part employed a 5-point Likerttype scale, with points on the scale indicating measures ranging from very willing, willing, neutral, unwilling, and totally not willing. The participants were anonymous and contained no identifiable information about the participants. Participation in this study was completely voluntary, and the questionnaires took approximately 5 minutes to complete.

A questionnaire created using Google survey forms was distributed thereafter through social media outlets such as Twitter and the WhatsApp application.

\section{Statistical Analysis}

Data were collected and analyzed and then summarized and presented in tables. All statistical analyses were performed using the Statistical Package for Social Sciences program (version 22). Descriptive statistics such as frequency distributions were performed. We used $t$-tests, one-way analysis of variance (ANOVA), and post hoc analysis to measure the relationship between variables. $P$ values $\leq .05$ were considered statistically significant.

\section{Results}

A total of 573 completed questionnaires. Table 1 presents the participants' sociodemographic data and sample characteristics. The majority of the respondents were in the age range $20-30$ years $41.4 \%$, followed by $31-40,29 \%$. More than two third of the sample were $(71.6 \%)$ bachelor holders.

Table I Sociodemographic and Characteristics of the Sample

\begin{tabular}{|c|c|c|}
\hline \multirow[t]{2}{*}{ Variables } & \multicolumn{2}{|l|}{ Gender } \\
\hline & Male & Female \\
\hline \multicolumn{3}{|l|}{ Age (years) } \\
\hline $18-20$ & $\mathrm{I}(0.2)$ & $47(8.2)$ \\
\hline $21-30$ & $54(9.4)$ & $183(31.9)$ \\
\hline $31-40$ & $59(10.3)$ & $107(18.7)$ \\
\hline $41-50$ & $25(4.4)$ & $6 I(10.6)$ \\
\hline $5 \mathrm{I}$ and older & $10(1.7)$ & $26(4.5)$ \\
\hline \multicolumn{3}{|l|}{ Marital status } \\
\hline Single & $68(11.9)$ & $204(35.6)$ \\
\hline Married & $80(14)$ & $198(34.6)$ \\
\hline Widow/divorced & $I(0.2)$ & $22(3.8)$ \\
\hline \multicolumn{3}{|l|}{ Education } \\
\hline Primary/middle school & $2(0.3)$ & $14(2.4)$ \\
\hline High school & $2 \mathrm{I}(3.7)$ & $60(10.5)$ \\
\hline Bachelor's degree & $101(17.6)$ & $309(53.9)$ \\
\hline Postgraduate degree & $25(4.4)$ & $4 I(7.2)$ \\
\hline \multicolumn{3}{|l|}{ Occupation } \\
\hline Does not work & $8(1.4)$ & $|2|(2||)$. \\
\hline Student & $24(4.2)$ & $136(23.7)$ \\
\hline Health care worker & $13(2.3)$ & $9(1.6)$ \\
\hline Governmental employee/private/other & $104(18.2)$ & $158(27.6)$ \\
\hline \multicolumn{3}{|l|}{ Have you received dental treatment before? } \\
\hline Yes & $147(25.7)$ & $408(7 I .2)$ \\
\hline No & $2(0.3)$ & $16(2.8)$ \\
\hline \multicolumn{3}{|l|}{ Last dental visit } \\
\hline For emergency & $16(9.1)$ & $52(9.1)$ \\
\hline \multicolumn{3}{|l|}{ Had dental appointment } \\
\hline Less than 6 months & $57(9.9)$ & $186(32.5)$ \\
\hline 6 to 12 months & $20(3.5)$ & $72(12.6)$ \\
\hline More than I year & $55(9.6)$ & $111(19.4)$ \\
\hline Other & $\mathrm{I}(0.2)$ & $3(0.5)$ \\
\hline \multicolumn{3}{|l|}{ Where do you receive your dental treatment? } \\
\hline Governmental hospitals & $25(4.4)$ & $64(11.2)$ \\
\hline Private clinics & III(19.4) & $334(58.3)$ \\
\hline Teaching hospital & $7(1.2)$ & $\mathrm{II}(\mathrm{I} .9)$ \\
\hline Governmental polyclinics & $6(1)$ & $15(2.6)$ \\
\hline \multicolumn{3}{|l|}{$\begin{array}{l}\text { Have you received any consultation or clinical } \\
\text { examination from a dentist regarding medical } \\
\text { condition? }\end{array}$} \\
\hline Yes & $3 I(5.4)$ & $62(10.8)$ \\
\hline No & $118(20.6)$ & $362(63.2)$ \\
\hline
\end{tabular}


Almost one third (30\%) were does not in health facilities and $27 \%$ were students. Five hundred fifty-five (96.9\%) had a previous dental visit, while 18 (3.1\%) individuals had never visited a dentist. Two hundred forty-three (42.4\%) had a dental appointment within the last 6 months. Most participants $(83.8 \%)$ did not receive any medical consultation in the dental office. The medical conditions among the participants are summarized in Figure 1.

Table 2 and Figure 2 show the willingness and attitudes of the study participants toward different aspects of chairside screening by their dentist. Participants who received a previous medical examination in the dental clinic were more accepting of obtaining a biopsy and undergoing medical consultations than others were (Table 3). Most participants were willing to let the dentist take their blood pressure $(89 \%)$. This was followed by an assessment of hypertension and diabetes mellitus $(85.7 \%$ and $83.1 \%$, respectively). Participants were also willing to undergo laboratory investigations requested by the dentist for medical conditions $(82.9 \%)$ and discussion of the result $(82.7 \%)$ as well as a general assessment of the health using questionnaires or preliminary evaluation $(80.5 \%)$ in the dental office. On the other hand, the lowest proportion reported a willingness to undergo simple biopsies such as swabs or surface scraping smear.
Most of the study population (85.7\%) stated that they were willing to receive a hypertension evaluation, which was significantly associated with age $(p=0.005)$. The Scheffe test indicated the most significant difference was between participants aged 20-30 years and those greater than 31 years. Participants in the 31-40 years and older age group were more willing to accept hypertension screening in the dental clinic setting. Willingness to undergo diabetes mellitus screening in the dental office was significant at $p=0.007$. Similarly, $83.1 \%$ of the sample were inclined to undergo diabetes screening in the dental office at $p=0.007$. The Scheffe post hoc test revealed a greater inclination for screening among participants aged 41-50 years than among those of younger age (20-30 years). As revealed by the ANOVA, willingness to undergo hepatic disease and cardiovascular screening was significant at $p=0.000005$, AIDS screening at $p=0.001$, and biopsy at $p=0.011$. The Scheffe post hoc test revealed that individuals aged 41-50 years had a tendency toward a willingness to undergo screening for both hepatic and cardiovascular diseases in the dental office. The ANOVA test indicated significant differences with regard to education levels and the willingness to receive chairside screening. The Scheffe post hoc test indicated that the willingness to undergo screening was lower among

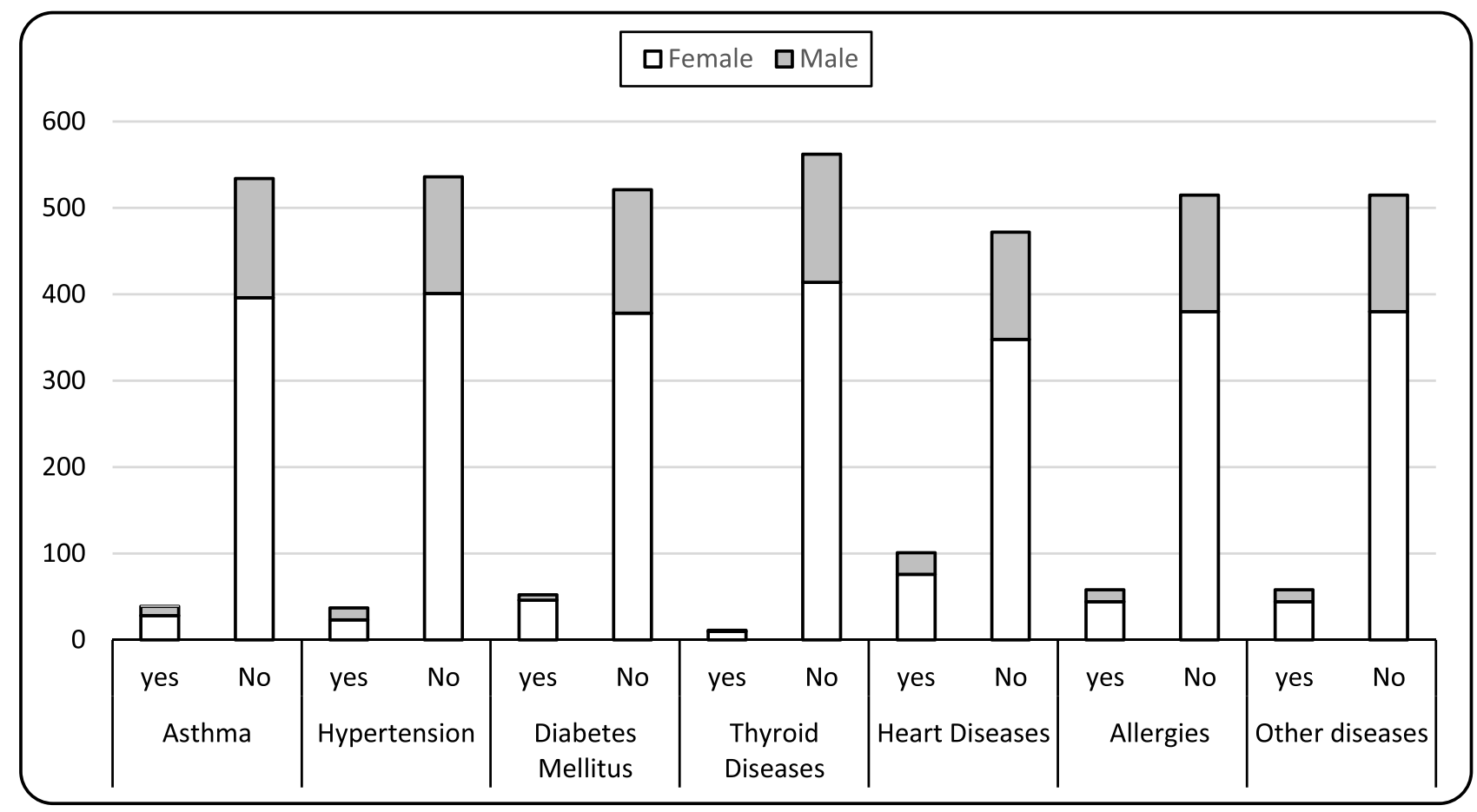

Figure I Graphical representation of the medical conditions of the sample. 
Table 2 How Willing Would You Be to Have Your Dentist Perform Screening for the Following Conditions in the Dental Office?

\begin{tabular}{|c|c|c|c|c|c|c|c|c|}
\hline Variables & Very Willing & Willing & Neutral & Not Willing & Totally Unwilling & Score Average & Std. Deviation & Order \\
\hline Hypertension screening & $36 I(63)$ & $130(22.7)$ & $56(9.8)$ & $20(3.5)$ & $6(1)$ & 4.4311 & 0.88156 & 2 \\
\hline Diabetes mellitus screening & $333(58.1)$ & $143(25)$ & $63(11)$ & $26(4.5)$ & $8(1.4)$ & 4.3386 & 0.94084 & 5 \\
\hline Hepatitis screening & $272(47.5)$ & $115(20.1)$ & $108(18.8)$ & $60(10.5)$ & $18(3.1)$ & 3.9825 & 1.16911 & 13 \\
\hline Cardiovascular disease screening & $265(46.2)$ & $134(23.4)$ & $93(16.2)$ & $62(10.8)$ & $19(3.3)$ & 3.9843 & 1.16539 & 12 \\
\hline AIDS screening & $293(5 I .1)$ & $102(17.8)$ & $94(16.4)$ & $65(11.3)$ & $19(3.3)$ & 4.0209 & 1.19567 & II \\
\hline Physical examination (wellness check) & $308(53.8)$ & $153(26.7)$ & $69(12.0)$ & $32(5.6)$ & II (1.9) & 4.2478 & 0.99721 & 7 \\
\hline Laboratory test & $331(57.8)$ & $144(25.1)$ & $67(11.7)$ & $25(4.4)$ & $6(1.0)$ & 4.3421 & 0.92077 & 4 \\
\hline Biopsy & $210(36.6)$ & $103(18.0)$ & $127(22.2)$ & 91 (15.9) & $42(7.3)$ & 3.6073 & 1.31602 & 14 \\
\hline Measuring blood pressure & $376(65.6)$ & $134(23.4)$ & $42(7.3)$ & $19(3.3)$ & $2(0.3)$ & 4.5061 & 0.79907 & 1 \\
\hline Measuring height & $321(56)$ & $100(17.5)$ & $87(15.2)$ & $43(7.5)$ & $22(3.8)$ & 4.1431 & 1.15742 & 8 \\
\hline Obtaining a blood sample & $300(52.4)$ & $126(22.0)$ & $83(14.5)$ & $46(8.0)$ & $18(3.1)$ & 4.1239 & 1.12209 & 9 \\
\hline Collecting a saliva sample & $279(48.7)$ & $155(27.1)$ & $80(14)$ & $43(7.5)$ & $16(2.8)$ & 4.1134 & 1.08036 & 10 \\
\hline Having a discussion about the results & $343(59.9)$ & $|3|(22.9)$ & $68(11.9)$ & $22(3.8)$ & $9(1.6)$ & 4.3560 & $0.94|8|$ & 3 \\
\hline Making medical consultations and referrals & $309(53.9)$ & 161 (28.1) & $70(12.2)$ & $23(4)$ & $10(1.7)$ & 4.2845 & 0.94853 & 6 \\
\hline Average & & & & & & 4.169016 & 0.806498 & \\
\hline
\end{tabular}

postgraduates and highest among those with a high school diploma. The willingness to undergo blood sampling was variable among the populations, but those who received their dental treatment in a governmental facility and those treated in the private sector were more reluctant than others $(p=0.016)$, as revealed by ANOVA and post hoc test. Table 4 presents the results.

\section{Discussion}

The current study was designed to assess the attitudes and knowledge of the public toward chairside dental screening and laboratory investigations and the effect of demographic data on their willingness. Medical screening by dentists for diagnosing high-risk patients and preventing complications is widely accepted as an effective
Make medical consultations \& referrals Result Discussion
Collect Saliva sample

Take Blood sample

Take the Height

Take the blood pressure Biopsy

Laboratory Test

Physical examination

AIDS
Cardiovascular Diseases
Hepatitis
Diabetes Mellitus
Hypertension

AIDS

年

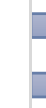
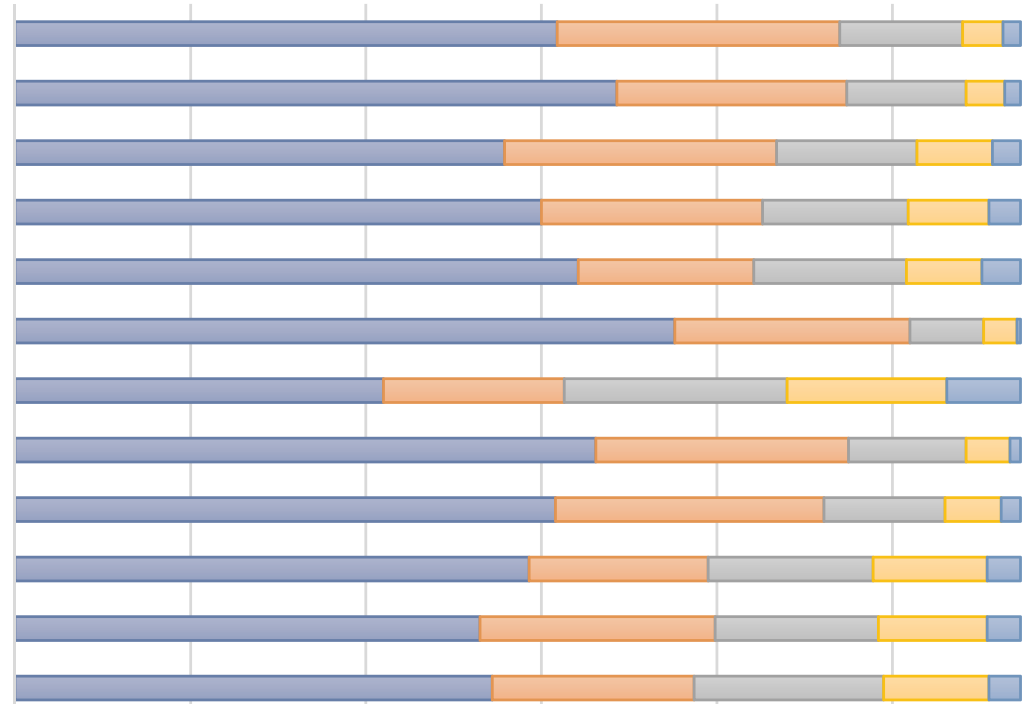

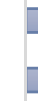
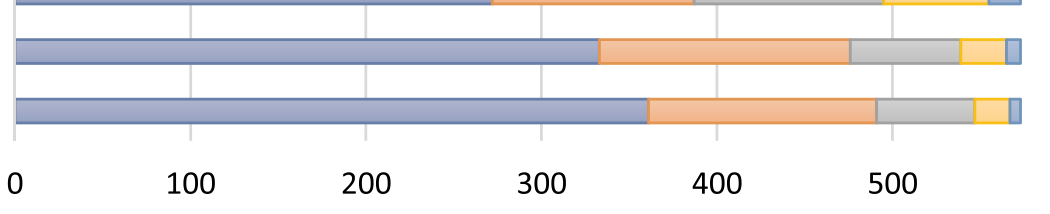

0

100

200

400

500

Figure 2 Willingness of the sample to have the dentist perform chairside screening for the selected conditions. 
Table $3 t$-Test of Analysis of Association Between Those Who Received a Medical Consultation or Examination from a Dentist Regarding Medical Condition in the Dental Office and Chairside Screening

\begin{tabular}{|l|l|l|l|l|l|l|}
\hline \multicolumn{2}{|l|}{$\begin{array}{l}\text { Have You Received Any Consultation or Clinical Examination from a Dentist } \\
\text { Regarding Medical Condition? }\end{array}$} & $\mathbf{n}$ & Mean & SD & $\boldsymbol{t}$ & Significance \\
\hline Perform simple biopsies (such as swabs) & $\begin{array}{l}\text { No } \\
\text { Yes }\end{array}$ & $\begin{array}{l}480 \\
93\end{array}$ & $\begin{array}{l}3.5542 \\
3.8817\end{array}$ & $\begin{array}{l}1.32472 \\
1.24105\end{array}$ & -2.304 & 0.023 \\
\hline Make medical consultation and referral & $\begin{array}{l}\text { No } \\
\text { Yes }\end{array}$ & $\begin{array}{l}480 \\
93\end{array}$ & $\begin{array}{l}4.2500 \\
4.4624\end{array}$ & 0.98845 & -2.525 & 0.08460 \\
\end{tabular}

measure. ${ }^{4,12,24}$ Indeed, one of the most recent objectives of the dental profession, as defined by the World Health Organization, is that dentists play a role in controlling diseases through medical visits, which will increase the population of subjects who receive preventive measures. $^{25}$
In general, most of the participants showed a willingness toward several aspects of chairside dental screening and agreed that screening for medical conditions should be implemented in the dental clinic. Several studies reported that most patients attending dental clinics thought that it is essential for dentists to screen patients for medical

Table 4 Association of Sample Characteristics with Perception and Attitudes Using ANOVA Test

\begin{tabular}{|c|c|c|c|c|c|c|c|}
\hline \multicolumn{2}{|l|}{ Variables } & \multirow[b]{2}{*}{$\begin{array}{l}\text { Between groups } \\
\text { Within groups } \\
\text { Total }\end{array}$} & \multirow{2}{*}{$\begin{array}{l}\text { Sum of Squares } \\
11.410 \\
433.117 \\
444.527\end{array}$} & \multirow{2}{*}{$\begin{array}{l}d f \\
4 \\
568 \\
572\end{array}$} & \multirow{2}{*}{$\begin{array}{l}\text { Mean Square } \\
2.852 \\
0.763\end{array}$} & \multirow{2}{*}{$\begin{array}{l}\boldsymbol{F} \\
3.741\end{array}$} & \multirow{2}{*}{$\begin{array}{l}\text { Significance } \\
0.005\end{array}$} \\
\hline Age & Hypertension & & & & & & \\
\hline & Diabetes mellitus & $\begin{array}{l}\text { Between groups } \\
\text { Within groups } \\
\text { Total }\end{array}$ & $\begin{array}{l}12.317 \\
494.001 \\
506.318\end{array}$ & $\begin{array}{l}4 \\
568 \\
572\end{array}$ & $\begin{array}{l}3.079 \\
0.870\end{array}$ & 3.541 & 0.007 \\
\hline & Hepatitis & $\begin{array}{l}\text { Between groups } \\
\text { Within groups } \\
\text { Total }\end{array}$ & $\begin{array}{l}40.199 \\
741.626 \\
781.825\end{array}$ & $\begin{array}{l}4 \\
568 \\
572\end{array}$ & $\begin{array}{l}10.050 \\
1.306\end{array}$ & 7.697 & 0.000 \\
\hline & Cardiovascular diseases & $\begin{array}{l}\text { Between groups } \\
\text { Within groups } \\
\text { Total }\end{array}$ & $\begin{array}{l}34.263 \\
742.595 \\
776.859\end{array}$ & $\begin{array}{l}4 \\
568 \\
572\end{array}$ & $\begin{array}{l}8.566 \\
1.307\end{array}$ & 6.552 & 0.000 \\
\hline & AIDS & $\begin{array}{l}\text { Between groups } \\
\text { Within groups } \\
\text { Total }\end{array}$ & $\begin{array}{l}25.958 \\
791.791 \\
817.749\end{array}$ & $\begin{array}{l}4 \\
568 \\
572\end{array}$ & $\begin{array}{l}6.490 \\
1.394\end{array}$ & 4.655 & 0.001 \\
\hline & Biopsy & $\begin{array}{l}\text { Between groups } \\
\text { Within groups } \\
\text { Total }\end{array}$ & $\begin{array}{l}22.316 \\
968.334 \\
990.649\end{array}$ & $\begin{array}{l}4 \\
568 \\
572\end{array}$ & $\begin{array}{l}5.579 \\
1.705\end{array}$ & 3.272 & 0.011 \\
\hline \multirow[t]{4}{*}{ Education } & AIDS & $\begin{array}{l}\text { Between groups } \\
\text { Within groups } \\
\text { Total }\end{array}$ & $\begin{array}{l}14.529 \\
803.219 \\
817.749\end{array}$ & $\begin{array}{l}3 \\
569 \\
572\end{array}$ & $\begin{array}{l}4.843 \\
1.412\end{array}$ & 3.431 & 0.017 \\
\hline & Biopsy & $\begin{array}{l}\text { Between groups } \\
\text { Within groups } \\
\text { Total }\end{array}$ & $\begin{array}{l}16.194 \\
974.455 \\
990.649\end{array}$ & $\begin{array}{l}3 \\
569 \\
572\end{array}$ & $\begin{array}{l}5.398 \\
1.713\end{array}$ & 3.152 & 0.025 \\
\hline & Obtaining blood sample & $\begin{array}{l}\text { Between groups } \\
\text { Within groups } \\
\text { Total }\end{array}$ & $\begin{array}{l}18.516 \\
701.686 \\
720.202\end{array}$ & $\begin{array}{l}3 \\
569 \\
572\end{array}$ & $\begin{array}{l}6.172 \\
1.233\end{array}$ & 5.005 & 0.002 \\
\hline & Collecting saliva sample & $\begin{array}{l}\text { Between groups } \\
\text { Within groups } \\
\text { Total }\end{array}$ & $\begin{array}{l}11.505 \\
656.121 \\
667.627\end{array}$ & $\begin{array}{l}3 \\
569 \\
572\end{array}$ & $\begin{array}{l}3.835 \\
1.153\end{array}$ & 3.326 & 0.019 \\
\hline
\end{tabular}


conditions and were very willing to be screened by a member of the dental team. ${ }^{13,15,17,21,22,26}$ Patients' willingness is essential for adopting such an approach. Implementing this strategy can assist in the early diagnosis and prevention of diseases and complications or delaying their occurrence. However, patients should receive adequate medical education about these conditions and dental clinic screening.

Our results demonstrated that the receipt of a previous consultation, referral, or biopsy in dental clinics affected the participant's willingness of undergoing this screening again. Similarly, Lawal and Oladayo reported that those with previous dental visits were better recipients for dental education. ${ }^{27}$ This may indicate that patient education and involvement are necessary to appreciate the advantages of this strategy. Studies have demonstrated that patient education increases compliance and improves oral health. ${ }^{28-30}$

In line with findings of previous studies by Lawal and Oladayo and Navabi et al, our results demonstrated a significant association between education level and willingness to undergo chairside screening. ${ }^{22,27}$ However, our results also indicated that participants holding a postgraduate degree were significantly less willing to undergo biopsy and AIDS screening in the dental office. Education level has been reported to be related to low oral health knowledge. Indeed, the level of education is one of the predictors of oral health status. ${ }^{4,30-32}$

Despite the fact that our sample included participants with chronic diseases, the medical condition did not play a role in their willingness to undergo screening. Our results demonstrated that a higher percentage of participants agreed to be screened for measuring blood pressure and hypertension assessment followed by a discussion of the results and requesting laboratory testing. Higher responses were also observed among patients in the literature. ${ }^{13,15,17}$ Trogdon et al reported that there is a large cost burden for hypertension because of its high prevalence. ${ }^{33}$ Interestingly, medical screening for hypertension in the dental office has been reported to reduce health care costs. ${ }^{12,33}$ Furthermore, studies have found that most patients who were willing to be screened in the dental clinic perceived the importance of the screening and had awareness of medical conditions. ${ }^{21,27} \mathrm{In}$ addition, chronic diseases, although preventable, have an effect and a burden on the economy and quality of life. ${ }^{34}$ Moreover, previous research has demonstrated that chairside screening can identify patients who are at increased risk of chronic disease yet are unaware of that increased risk. $^{7,21}$
In accordance with the findings of other studies, ${ }^{17,22}$ we found that a large percentage of the participants were willing to undergo blood pressure examination, laboratory tests, saliva sample collection, and discussion of the results with the dentist. Laboratory test findings and physician referrals were found to be of significance and fulfill the responsibilities of dentists toward their patients. ${ }^{35,36}$ This is important for improving the overall health care delivered for the patients. The dentist may discover many incidental finings during clinical or radiographic examination for dental patients. ${ }^{37}$ Many studies have reported incidental findings found in dental radiographs. Some of these findings may require further investigations to rule out life threatening conditions such as carotid artery calcifications seen on panoramic radiographs or signs of bone destructions or malignancy within the Maxillary sinuses. ${ }^{38,39}$ Such cases require medical referrals and further investigations. Furthermore, some medical conditions and syndromes might be diagnosed in some cases by radiographic features on dental radiographs such as Gardner's syndrome, osteoporosis or other systematic conditions as well. ${ }^{40,41}$ Therefore, the willingness of patient and understanding of the dentist's role in making medical consultations and referrals is important in providing holistic health care and improving the quality of patients' lives.

Alternatively, some of the participants reported an unwillingness to perform a biopsy and AIDS test. A similar result was reported by Brondani et al, but their findings were in contrast to others who reported wide acceptance of AIDS testing in the dental clinics. ${ }^{42-45}$ Different sample characteristics and communities may play a role in the disparities in acceptance. In 2019, Kassim et al explained that HIV testing is not accessible and carries a huge stigma among the studied population. ${ }^{14}$ Siegel et al reported that, among dentists, one of the barriers to offering HIV testing was to avoid offending patients, as this test is less likely to be accepted by patients as well as to prevent the negative impact on the practice. ${ }^{46}$

This investigation documented the wide acceptance of medical screening in the dental setting. As reported in the literature, medical screening could aid in the prevention of diseases among high-risk individuals. ${ }^{19,20,47,48,49}$ It may also assist in controlling disease and preventing complications, thus reducing morbidity and mortality, as well as ease the economic and social burden of chronic diseases. ${ }^{19,20,47,48,49}$ 


\section{Conclusions}

The current study intended to evaluate the attitudes and knowledge of the public toward chairside dental screening and laboratory investigations and to analyze the results based on demographic data. In general, most of the participants were willing to undergo chairside screening performed by the dentist. Several factors significantly affected participants' responses, including age group, sex, marital status, occupation, level of education, previous dental experience, and medical conditions. Adequate training for medical screening should be implemented in the dental curriculum as well as in continuing medical education. There is a strong need to emphasize the benefits of increased cooperation between dentistry and other health care professions. To obtain more acceptance of chairside screening, community education programs should be implemented.

\section{Data Sharing Statement}

Data are available and can be provided upon request.

\section{Ethics Approval and Informed Consent}

Ethical approval was obtained from Research Ethics Committee, Deanship of Scientific Research, King Saud University, Riyadh, Saudi Arabia (KSU-IRB 017E). Participation was voluntary, and consent was obtained prior to contribution. All participations were informed about the purpose of the study before contribution. This study was conducted in accordance with the Declaration of Helsinki.

\section{Consent for Publication}

The authors have given their consent that the details of any images, videos, recordings, etc., can be published, and that the persons providing consent have been shown the article contents to be published.

\section{Acknowledgments}

The authors would like to express their deepest thanks to the Researchers Support and Services Unit at King Saud University for their editorial assistance.

\section{Funding}

This research project was supported by a grant from the "Research Center of the Female Scientific and Medical Colleges", Deanship of Scientific Research, King Saud University.

\section{Disclosure}

The authors report no conflicts of interest in this work.

\section{References}

1. Jadhav AN, Tarte PR, Puri SK. Dental clinic: potential source of high-risk screening for prediabetes and type 2 diabetes. Indian J Dent Res. 2019;30(6):851. doi:10.4103/ijdr.IJDR 8018

2. Herman WH, Burke R, Taylor GW, Jacobson JJ, Brown MB. Screening for prediabetes and type 2 diabetes in dental offices. J Public Health Dent. 2015;75(3):175-182. doi:10.1111/jphd.12082

3. Giddon DB, Swann B, Donoff RB, Hertzman-Miller R. Dentists as oral physicians: the overlooked primary health care resource. J Prim Prev. 2013;34(4):279-291. doi:10.1007/s10935-013-0310-7

4. Nasseh K, Greenberg B, Vujicic M, Glick M. The effect of chairside chronic disease screenings by oral health professionals on health care costs. Am J Public Health. 2014;104(4):744-750. doi:10.2105/ AJPH.2013.301644

5. Jontell M, Glick M. Oral health care professionals' identification of cardiovascular disease risk among patients in private dental offices in Sweden. J Am Dent Assoc. 2009;140(11):1385-1391. doi:10.14219/ jada.archive.2009.0075

6. Friman G, Wårdh I, Nilsson G, Hultin M. Identifying patients in dental settings at risk of cardiovascular disease and diabetes. Cardiovasc Syst. 2013;1:5. doi:10.7243/2052-4358-1-5

7. Strauss SM, Alfano MC, Shelley D, Fulmer T. Identifying unaddressed systemic health conditions at dental visits: patients who visited dental practices but not general health care providers in 2008. Am J Public Health. 2012;102(2):253-255. doi:10.2105/ AJPH.2011.300420

8. Glick M, Greenberg BL. The potential role of dentists in identifying patients' risk of experiencing coronary heart disease events. $J$ Am Dent Assoc. 2005;136(11):1541-1546. doi:10.14219/jada. archive.2005.0084

9. Almoznino G, Aframian DJ, Sharav Y, Sheftel Y, Mirzabaev A, Zini A. Lifestyle and dental attendance as predictors of oral health-related quality of life. Oral Dis. 2015;21(5):659-666. doi:10.1111/odi.12331

10. Wilson N. Holistic care should be coming your way. Br Dent J. 2017;223(8):568-569. doi:10.1038/sj.bdj.2017.878

11. Bowen DM. Medical screenings in dental settings. J Dent Hyg. 2012;86(4):260-264.

12. Friman G, Hultin M, Nilsson GH, Wårdh I. Medical screening in dental settings: a qualitative study of the views of authorities and organizations health services research. BMC Res Notes. 2015;8(1). doi:10.1186/s13104-015-1543-8

13. Bakare T, Okoturo E, Obisesan B, Oyapero A. Patients' attitudes toward screening for medical conditions in a dental clinic at the Lagos State University Teaching Hospital, Ikeja. Int $J$ Health Allied Sci. 2018;7(3):150-158. doi:10.4103/ijhas.IJHAS_110_17

14. Kassim S, Othman B, AlQahtani S, Kawthar AM, McPherson SM, Greenberg BL. Dentists' attitudes towards chairside medical conditions screening in a dental setting in Saudi Arabia: an exploratory cross-sectional Study. BMC Oral Health. 2019;19(1):1-8. doi:10.1186/s12903-019-0870-x

15. Greenberg BL, Kantor ML, Jiang SS, Glick M. Patients' attitudes toward screening for medical conditions in a dental setting. $J$ Public Health Dent. 2012;72(1):28-35. doi:10.1111/j.1752-7325.2011.0 0280.x

16. Creanor S, Millward BA, Demaine A, et al. Patients ${ }^{6}$ attitudes towards screening for diabetes and other medical conditions in the dental setting. Br Dent J. 2014;216(1). doi:10.1038/sj.bdj.2013.1247

17. Sansare K, Raghav M, Kasbe A, et al. Indian patients' attitudes towards chairside screening in a dental setting for medical conditions. Int Dent J. 2015;65(5):269-276. doi:10.1111/idj.12175 
18. World Health Organization. World Health Statistics Overview 2019: Monitoring Health for the SDGs, Sustainable Development Goals. Geneva: World Health Organization; 2019:9789241565707.

19. Kalladka M, Greenberg BL, Padmashree SM, et al. Screening for coronary heart disease and diabetes risk in a dental setting. Int J Public Health. 2014;59(3):485-492. doi:10.1007/s00038-013-0530-X

20. AlGhamdi AST, Bukhari SMN, Elias WY, Merdad K, Sonbul H. Dental clinics as potent sources for screening undiagnosed diabetes and prediabetes. Am J Med Sci. 2013;345(4):331-334. doi:10.1097/ MAJ.0b013e318287c96c

21. Tantipoj C, Hiransuthikul N, Supa-amornkul S, Lohsoonthorn V, Khovidhunkit S-OP. Patients' attitude toward diabetes mellitus screening in Thai dental clinics. J Health Res. 2018;32(1):2-11. doi:10.1108/JHR-11-2017-001

22. Navabi N, Zeynali M, Mansori M, Hashemipour MA, Nassab SARG. Patients attitudes' toward chairside medical screening in a dental setting. Pesqui Bras Odontopediatria Clin Integr. 2020;20:e4880. doi:10.1590/pboci.2020.080

23. Friman G, Golestani G, Kalkali A, Wårdh I, Hultin M. Patient experiences of medical screening performed by the dental services: a qualitative study. Open $J$ Stomatol. 2013;3(09):497-503. doi:10.4236/ojst.2013.39081

24. Greenberg BL, Glick M. Screening for unidentified increased systemic disease risk in a dental setting. Am J Public Health. 2012;102 (7):e10. doi:10.2105/AJPH.2012.300729

25. Centers for Disease Control and Prevention. Department of health and human services. Healthy people 2020. 2020. Available from: https://www. healthypeople.g.,ov/2020/topics-objectives. Accessed January 18, 2021.

26. Greenberg BL, Glick M, Frantsve-Hawley J, Kantor ML. Dentists' attitudes toward chairside screening for medical conditions. J Am Dent Assoc. 2010;141(1):52-62. doi:10.14219/jada.archive.2010.0021

27. Lawal FB, Oladayo AM. Sources and factors related to oral health-care information among dental patients of a teaching hospital in Ibadan, Nigeria. Int Q Community Health Educ. 2019;40(1):17-22. doi:10.1177/0272684X19833847

28. Alzoubi M, Borg V, Gatt G, Aguis A, Attard N. The importance of oral health education in patients receiving orthodontic treatment. J Oral Res Rev. 2019;11(1):12-19. doi:10.4103/jorr.jorr_24_18

29. Kikuchi K, Yasuoka J, Tuot S, et al. Improving overall health of children living with HIV through an oral health intervention in Cambodia: study protocol for a randomized controlled trial. Trials. 2018;19(1):673. doi:10.1186/s13063-018-3047-z

30. Saffan ADA 1, Baseer MA 1, Alshammary AA 1, Rahman G 1, Assery M 2, Kamel A 2. Impact of oral health education on oral health knowledge of private school children in Riyadh city, Saudi Arabia. J Int Soc Prev Community Dent. 2018;7:S186-S193. doi:10.4103/jispcd.JISPCD_372_17

31. Márquez-Arrico C-F, Almerich-Silla J-M, Montiel-Company J-M. Oral health knowledge in relation to educational level in an adult population in Spain. J Clin Exp Dent. 2019;11(12):e1143-e1150. doi: $10.4317 /$ jced.56411

32. Paulander J, Axelsson P, Lindhe J. Association between level of education and oral health status in 35-, 50-, 65- and 75-year-olds. $J$ Clin Periodontol. 2003;30(8):697-704. doi:10.1034/j.1600051x.2003.00357.x

33. Trogdon JG, Finkelstein EA, Nwaise IA, Tangka FK, Orenstein D. The economic burden of chronic cardiovascular disease for major insurers. Health Promot Pract. 2007;8(3):234-242. doi:10.1177/ 1524839907303794
34. Gadd J. Chronic crisis: burden of chronic disease on preventable deaths. Aust Nurs Midwifery J. 2018;25(11):18-23.

35. Sabes WR, Green S, Craine C. Value of medical diagnostic screening tests for dental patients. J Am Dent Assoc. 1970;80(1):133-136. doi:10.14219/jada.archive.1970.0016

36. Sonis ST, Fazio R, Setkowicz A, Gottlieb D, Vorhaus C. Comparison of the nature and frequency of medical problems among patients in general, specialty and hospital dental practices. J Oral Med. 1983;38(2):58-61.

37. MacDonald D, Yu W. Incidental findings in a consecutive series of digital panoramic radiographs. Imaging Sci Dent. 2020;50(1):53-64. doi:10.5624/isd.2020.50.1.53

38. Almog DM, Illig KA, Carter LC, Friedlander AH, Brooks SL, Grimes RM. Diagnosis of non-dental conditions. Carotid artery calcifications on panoramic radiographs identify patients at risk for stroke. N Y State Dent J. 2004;70(8):20-25.

39. Ohba T, Langlais RP, Langland OE. Clinical significance of the panoramic innominate line in the diagnosis of a maxillary sinus carcinoma. Oral Surg Oral Med Oral Pathol. 1993;76(4):533-536. doi:10.1016/0030-4220(93)90025-y

40. Adisen MZ, Okkesim A, Misirlioglu M. The importance of early diagnosis of Gardner's syndrome in dental examination. Niger J Clin Pract. 2018;21(1):114-116. doi:10.4103/njcp.njcp_381_16

41. Taguchi A, Ohtsuka M, Nakamoto T, Tanimoto K. Screening for osteoporosis by dental panoramic radiographs. Clin Calcium. 2006;16(2):291-297.

42. Brondani M, Chang S, Donnelly L. Assessing patients' attitudes to opt-out HIV rapid screening in community dental clinics: a crosssectional Canadian experience. BMC Res Notes. 2016;9:264. doi:10.1186/s13104-016-2067-6

43. Dietz CA, Ablah E, Reznik D, Robbins DK. Patients' attitudes about rapid oral HIV screening in an urban, free dental clinic. AIDS Patient Care STDS. 2008;22(3):205-212. doi:10.1089/apc.2007.0235

44. Bradley ELP, Vidot DC, Gaul Z, Sutton MY, Pereyra M, Milgrom PM. Acceptability of oral rapid HIV testing at dental clinics in communities with high HIV prevalence in South Florida. PLoS One. 2018;13(4):1-12. doi:10.1371/journal.pone.0196323

45. Van Devanter N, Combellick J, Hutchinson MK, Phelan J, Malamud D, Shelley DA. Qualitative study of patients' attitudes toward HIV testing in the dental setting. Nurs Res Pract. 2012;1-6. doi:10.1155/2012/803169

46. Siegel K, Abel SN, Pereyra M, et al. Rapid HIV testing in dental practices. Am J Public Health. 2012;102(4):625-632. doi:10.2105/ AJPH.2011.300509

47. Li G, Zhang P, Wang J, et al. The long-term effect of lifestyle interventions to prevent diabetes in the China Da Qing Diabetes Prevention Study: a 20-year follow-up study. Lancet. 2008;371 (9626):1783-1789. doi:10.1016/S0140-6736(08)60766-7

48. Lalla E, Kunzel C, Burkett S, et al. Identification of unrecognized diabetes and pre-diabetes in a dental setting. J Dent Res. 2011;90 (7):855-860. doi:10.1177/0022034511407069

49. Lamster IB, Eaves K. A model for dental practice in the 21 st century. Am J Public Health. 2011;101(10):1825-1830. doi:10.2105/ AJPH.2011.300234 


\section{Publish your work in this journal}

Patient Preference and Adherence is an international, peer-reviewed, open access journal that focusing on the growing importance of patient preference and adherence throughout the therapeutic continuum. Patient satisfaction, acceptability, quality of life, compliance, persistence and their role in developing new therapeutic modalities and compounds to optimize clinical outcomes for existing disease

states are major areas of interest for the journal. This journal has been accepted for indexing on PubMed Central. The manuscript management system is completely online and includes a very quick and fair peer-review system, which is all easy to use. Visit http:// www.dovepress.com/testimonials.php to read real quotes from published authors.

Submit your manuscript here: https://www.dovepress.com/patient-preference-and-adherence-journal 